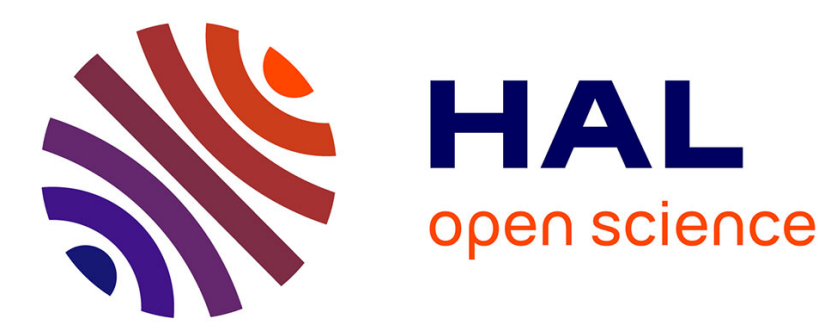

\title{
Analysis of the relationships between species of the genus Prosopis revealed by the use of molecular markers
}

Lucía Ramírez, Alicia de La Vega, Nerea Razkin, Virginia Luna, Philip J.C.

Harris

\section{- To cite this version:}

Lucía Ramírez, Alicia de La Vega, Nerea Razkin, Virginia Luna, Philip J.C. Harris. Analysis of the relationships between species of the genus Prosopis revealed by the use of molecular markers. Agronomie, 1999, 19 (1), pp.31-43. hal-00885911

\section{HAL Id: hal-00885911 https://hal.science/hal-00885911}

Submitted on 1 Jan 1999

HAL is a multi-disciplinary open access archive for the deposit and dissemination of scientific research documents, whether they are published or not. The documents may come from teaching and research institutions in France or abroad, or from public or private research centers.
L'archive ouverte pluridisciplinaire HAL, est destinée au dépôt et à la diffusion de documents scientifiques de niveau recherche, publiés ou non, émanant des établissements d'enseignement et de recherche français ou étrangers, des laboratoires publics ou privés. 


\title{
Original article
}

\section{Analysis of the relationships between species of the genus Prosopis revealed by the use of molecular markers}

\author{
Lucía Ramírez $^{\text {a }}$, Alicia de la Vega ${ }^{\mathrm{a}, \mathrm{b}}$, Nerea Razkin ${ }^{\mathrm{a}}$, Virginia Luna ${ }^{\mathrm{c}}$, Philip J.C. Harris ${ }^{\mathrm{d}}$ \\ ${ }^{a}$ Departamento de Producción Agraria, Universidad Pública de Navarra, 31006 Pamplona, Spain.

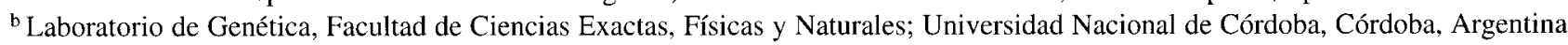 \\ ${ }^{\mathrm{c}}$ Laboratorio de Fisiología Vegetal, Departamento de Ciencias Naturales, Fac. de Ciencias Exactas, Físico-Químicas y Naturales, \\ Universidad Nacional de Río Cuarto, Río Cuarto, Argentina \\ ${ }^{d}$ School of Natural and Environmental Sciences, Coventry University, Priory Street, Coventry, CV1 5FB, UK
}

(Received 6 December 1998, accepted 25 December 1998)

\begin{abstract}
The 44 species of the genus Prosopis L. include several which are utilised as multipurpose trees and shrubs within their natural range and as exotics in plantation programmes. However, domestication and exploitation of the genus has been hampered by poor understanding of its taxonomy. Randomly amplified polymorphisms of DNA (RAPD) from cotyledons were used to analyse the taxonomy of 15 Prosopis species from Sénégal, India and Argentina. Molecular markers were identified which were present in all species analysed, only in American species, specific to the section Strombocarpa, or specific to the section Algorobia, except $P$. kuntzei. The different RAPD profiles showed by $P$. kuntzei suggest a low degree of relatedness of this species to the other Prosopis analysed. The use of RAPDs markers clearly distinguished the five sections of the genus. The profiles obtained for $P$. argentina in the monospecific section Monilicarpa confirm the distinct character of this species. However, the results suggest that regrouping of species within the section Algarobia may be required. (@ Inra/Elsevier, Paris.)
\end{abstract}

\section{Prosopis / RAPD / taxonomy}

Résumé - Analyse des relations interspécifiques dans le genre Prosopis par l'utilisation de marqueurs RAPD. Parmi les 44 espèces du genre Prosopis L. plusieurs sont utilisées comme des arbres ou des arbustes à usage multiple, dans leur biotope naturel ou comme plantes exotiques ailleurs. Cependant, la domestication et l'exploitation de ce genre sont freinées par notre faible connaissance de sa taxonomie. Les polymorphismes d'ADN amplifiés au hasard (RAPD) à partir des cotylédons ont été analysés pour étudier les relations taxonomiques entre 15 espèces de Prosopis originaires du Sénégal, d'Inde ou d'Argentine. Des marqueurs moléculaires ont été identifiés présents dans toutes les espèces exam-

Communicated by Nicolás Jouve (Madrid, Spain)

* Correspondence and reprints

E-mail: Iramirez@upna.es 
inées, présents uniquement dans les espèces américaines, spécifiques de la section Strombocarpa, ou spécifiques de la section Algorobia, P.kuntzei excepté. Les profils RAPD de P.kuntzei suggèrent un faible degré d'homologie avec les autres Prosopis analysés. Les marqueurs RAPD permettent de distinguer clairement les cinq sections du genre. Les profils présentés par P.argentina de la section monospécifique Monilicarpa confirment le caractère particulier de cette espèce. Cependant, les résultats obtenus suggèrent que des regroupements d'espèces au sein de la section Algarobia pourraient s'avérer nécessaires. (ㅇ Inra/Elsevier, Paris.)

\section{Prosopis / RAPD / taxonomie}

\section{INTRODUCTION}

The genus Prosopis (Linnaeus, emend Burkart) is one of the most primitive genera within the family Leguminosae (Fabaceae), subfamily Mimosoidae. Currently, it is accepted that the genus includes 44 species with tree or shrub phenotypes. Most species are predominantly outcrossing with insect-mediated pollination $[36,37]$ and are prolific seed producers, with hybridisation and introgression occurring commonly. Burkart $[7,8]$ divided the genus into five sections based on the marked vegetative differences in armature: section Anonychium comprising a solitary unarmed species, section Prosopis containing three species which have internodal prickles, section Monilicarpa which is mono-specific, section Strombocarpa containing nine species which have spiny stipules, and section Algarobia containing 30 species bearing cauline, mostly axillary thorns.

The genus Prosopis is thought to have originated in tropical Africa at the end of the Mesozoic or the beginning of the Tertiary period. Prosopis species are now widespread, mainly in the arid and semiarid tropics, suggesting that the ancestors of present days species may have migrated both west and the east $[7,8]$. It is assumed that the principal centre of origin for this genus in the Americas, where 40 out 44 species developed, is in Argentina, although a second centre of origin is found in the Texan-Mexican area $[7,8]$.

Species of the genus Prosopis can be found which are adapted to a variety of environmental conditions with many adapted to drought [39] and high temperatures [13]. Prosopis species are generally able to grow in poor or degraded soils [26] and some species exhibit a high degree of salt tolerance [14]. Prosopis species have long been utilised in areas where they occur naturally, predominantly in the desert regions of South Asia, and North and South America [16]. Prosopis species are multipurpose [16] providing a range of products including timber, firewood, livestock feed, human food and beverages, fibres and tannins. They are also valued for shade, shelter belts, bee forage and as nitrogenfixing soil improvers. The potential of Prosopis for afforestation of arid lands has long been recognised and, in recent decades, there have been several large scale plantation programmes with both indigenous and exotic Prosopis species [16].

The domestication and exploitation of the genus Prosopis has, however, been hampered by a poor understanding of its taxonomy and by the somewhat haphazard transfer of Prosopis species from their natural range to new areas. Thus, confusion exists as to the identity of promising material in situ in South America where it is unclear whether $P$. juliflora, $P$. pallida or hybrids of these offer the superior material [16]. Similarly, with introduced species, the identity at species level is sometimes unclear and the result of poorly documented introductions with no information as to ecotype or provenance [16]. These problems make it necessary to develop techniques to assist taxonomists in the rapid and conclusive identification of Prosopis material.

Molecular markers based on DNA polymorphism are easy-scored genetic characters, independent of the environment, that can assist in species identification and classification. There is a plethora of molecular markers based on the polymerase chain reaction (PCR) and over the last 10 years a large body of information about them has accumu- 
lated [15, 42]. These markers have been used in wild plants to uncover genetic diversity and relatedness in plant populations, to measure the influence of breeding systems on diversity, and in plant taxonomy $[4,9,10,17,20]$. With cultivated plants they have been used in cultivar identification, to determine genetic relatedness among cultivars, for paternity testing, in the identification of hybrids and in genome mapping projects $[1-3,19,21,25,29,35$, $41,44]$.

In this paper we have used randomly amplified polymorphisms of DNA (RAPD) to analyse the complex taxonomy of the genus Prosopis. We have also determined the phylogenic relationships between species of this genus by comparing the restriction digestion patterns of genomic DNA and by means of DNA hybridisation experiments.

\section{MATERIALS AND METHODS}

\subsection{Plant material and culture conditions}

The species analysed in this study and their provenances are shown in table I. Their morphological char- acteristics are described by Burkart [7, 8]. About 20 seeds of each of the 15 species were rinsed for $5 \mathrm{~min}$ with sterile water containing $4 \mathrm{~g} \mathrm{~L}^{-1}$ of $\mathrm{HOCl}$, scarified by piercing the testas to allow water inflow, sown on damp filter paper in Petri dishes, and incubated in the dark at $37^{\circ} \mathrm{C}$ for $24 \mathrm{~h}$. After incubation, the testas were removed and the seeds were transferred to new Petri dishes containing filter paper moistened with sterile distilled water and germinated for approximately 1 week at $18^{\circ} \mathrm{C}$ with $12 \mathrm{~h}$ photoperiod and $80 \%$ relative humidity. One week old cotyledons from seedlings were harvested and stored individually at $-80^{\circ} \mathrm{C}$ until used.

\subsection{DNA manipulation}

Genomic DNA was obtained from cotyledons according to the protocol described by Lassner et al. [22] with the following modifications: $100 \mathrm{ng}$ of plant material (the average weight of two cotyledons of a single plant) were ground in a microcentrifuge tube containing $300 \mu \mathrm{L}$ of extraction buffer (100 mM Tris- $\mathrm{HCl}, 50 \mathrm{mM}$ EDTA, $500 \mathrm{mM} \mathrm{NaCl}, 10 \mathrm{mM} \beta$-mercaptoethanol, pH 8.0). After grinding, $700 \mu \mathrm{L}$ of extraction buffer and $400 \mu \mathrm{L}$ of chloroform/isoamyl alcohol (24:1 v/v) were added to the sample, mixed gently and incubated for $12 \mathrm{~min}$ at $55^{\circ} \mathrm{C}$. After incubation, the two phases were separated by centrifugation (15 min, $14000 \mathrm{rpm}$ in an eppendorf

Table I. The species of Prosopis analysed in this study and their provenances.

\begin{tabular}{|c|c|c|c|c|c|}
\hline Section & Series & Species & Locality & State & Country \\
\hline I. Prosopis & - & P. cineraria & - & Rajasthan, Haryana & India \\
\hline II. Anonychium & - & P. africana & - & - & Senegal \\
\hline III. Strombocarpa & Strombocarpae & P. strombulifera & $\mathrm{km} \mathrm{894,} \mathrm{km} 896$ & Córdoba & Argentina \\
\hline Strombocarpa & Strombocarpae & P. torquata & Nene Vergara, San Nicolás & Córdoba & Argentina \\
\hline Strombocarpa & Cavenicarpae & P. ferox & Quebradade Humahuaca & Jujuy & Argentina \\
\hline IV. Monilicarpa & - & P. argentina & Tucu-Tucu & Mendoza & Argentina \\
\hline V. Algarobia & Sericanthae & P. kuntzei & Puente Rio & Santiago Estero & Argentina \\
\hline Algarobia & Ruscifoliae & P. hassleri & Anillaco & La Rioja & Argentina \\
\hline Algarobia & Pallidae & P. affinis & Las Garzas & Entre Ríos & Argentina \\
\hline Algarobia & Chilensis & P. chilensis & Quilino & Córdoba & Argentina \\
\hline Algarobia & Chilensis & P. nigra & San Marcos & Córdoba & Argentina \\
\hline Algarobia & Chilensis & P. caldenia & Santa Rosa & La Pampa & Argentina \\
\hline Algarobia & Chilensis & P. flexиоsa & Villa Dolores & Córdoba & Argentina \\
\hline Algarobia & Chilensis & $P$. alba & km 882 & Córdoba & Argentina \\
\hline Algarobia & Chilensis & P. alba var. panta & Quilino & Córdoba & Argentina \\
\hline
\end{tabular}


microcentrifuge) and the supernatant was transferred to a new eppendorf tube, mixed with an equal volume of phe$\mathrm{nol} / \mathrm{chloroform} /$ isoamyl alcohol $(25: 24: 1 \mathrm{v} / \mathrm{v} / \mathrm{v})$ and centrifuged once more in the same conditions as before. The supernatant was recovered and the DNA precipitated by adding 1.2 volumes of cold $\left(-20^{\circ} \mathrm{C}\right) 2$-isopropanol and further incubation at $4{ }^{\circ} \mathrm{C}$ for at least $30 \mathrm{~min}$. The genomic DNA was collected by centrifugation in an eppendorf microcentrifuge at $14000 \mathrm{rpm}$ for $15 \mathrm{~min}$. The pellet was rinsed with $70 \%$ ethanol-10 mM sodium acetate, dried and dissolved in TE buffer (Tris HCl $10 \mathrm{mM}$, EDTA 1 $\mathrm{mM}, \mathrm{pH}$ 7.8). The RNA was removed by treatment with $25 \mu \mathrm{g} \mathrm{mL}^{-1}$ of RNAse and the DNA was deproteinised by $\mathrm{phenol} / \mathrm{chloroform} /$ isoamyl alcohol extraction. The genomic DNA was dissolved in sterile water to a final concentration of $20 \mathrm{ng} \mu \mathrm{L}^{-1}$. General molecular biology protocols were used as described by Sambroock et al. [34].

In order to generate RAPD markers specific for the species studied, pools of DNA containing equal amounts of DNA purified from ten individuals of the same species were used as templates [24]. Polymerase chain reactions (PCR) for the generation of the RAPD markers were performed as described by Williams et al. [43] in a reaction volume of $25 \mu \mathrm{L}$ containing $100 \mathrm{ng}$ of pooled DNA as template, $2 \mathrm{mM} \mathrm{MgCl}, 67 \mathrm{mM}$ Tris $\mathrm{HCl}(\mathrm{pH}$ 8.8), $16 \mathrm{mM}\left(\mathrm{NH}_{4}\right)_{2} \mathrm{SO}_{4}, 0.1 \mathrm{~g} \mathrm{~L}^{-1}$ Tween-20, $200 \mu \mathrm{M}$ each one of the four nucleotide triphosphates (ATP, CTP, GTP and TTP), $0.2 \mu \mathrm{M}$ of the primer oligonucleotide and one unit of Taq polymerase (Eurobiotaq, Ecogen, Barcelona, Spain). The oligonucleotides used as primers for the reaction were 10 -mers belonging to the $\mathrm{L}$ and $\mathrm{S}$ Operon series (Operon Technologies Inc., Alameda, California, USA). Amplification reactions were performed in a PTC-200 (Peltier Thermal Cycler, MJ Research, Watertown, Massachusetts, USA) using the following programme: 4 min of initial denaturation at $94{ }^{\circ} \mathrm{C}$ followed by 40 cycles of PCR reaction ( $1 \mathrm{~min}$ denaturation at $94^{\circ} \mathrm{C}, 1 \mathrm{~min}$ annealing at $37^{\circ} \mathrm{C}, 1.3 \mathrm{~min}$ extension at $72{ }^{\circ} \mathrm{C}$ ). Amplification products were analysed by electrophoresis in $1.6 \%(\mathrm{w} / \mathrm{v})$ agarose gels in TAE buffer $(400 \mathrm{mM}$ Tris, $200 \mathrm{mM}$ sodium acetate, $20 \mathrm{mM}$ EDTA, $\mathrm{pH} 8.3$ ) and stained with ethidium bromide. As molecular size markers $\Phi 29$ HindIII digested DNA was used. In those experiments in which the amplification products were detected by DNA hybridisation (see below), the number of cycles of the PCR reaction was reduced to 20 .

All RAPD reactions were repeated three times by three different persons to avoid the problems derived from low reproducibility of RAPD markers. Only those bands appearing consistently in all the experiments were used in the rest of the work.
In order to generate restricted randomly amplified polymorphic DNA markers (ReRAPD markers), genomic DNA purified from a single plant was completely digested with a given restriction endonuclease (according to the manufacturer's recommendations) before being used as a template for RAPD marker generation as described above. In this analysis, the RAPD profile obtained using either restricted and unrestricted DNA as templates are compared.

For the cloning of RAPD markers, the amplification products were separated by electrophoresis as described above and the bands of interest were extracted from the agarose gel using the liquid nitrogen method [40] and ligated to a pGEM-T plasmid (Promega, Southampton, UK). The recombinant plasmids were transformed into Echerichia coli DH5 $\alpha \mathrm{F}^{\prime}$ cells cultured in Luria-Bertani Broth (10 $\mathrm{g}$ of bactotryptone, $10 \mathrm{~g}$ yeast extract, $5 \mathrm{~g}$ $\mathrm{NaCl}, 1 \mathrm{~L} \mathrm{H}_{2} \mathrm{O}$; [23]) with $100 \mathrm{mg} \mathrm{mL}^{-1}$ ampicillin (Sigma, St Louis, Missouri, USA) at $37^{\circ} \mathrm{C}$ with shaking (200 rpm). The amplified fragments were recovered from the recombinant plasmid by digestion of it with ApaI and PstI restriction enzymes according to the manufacturer's conditions (Amersham, Buckinghamshire, UK). In order to use the purified fragments as probe for DNA hybridisation experiments, they were labelled with digoxygenine (DIG) according to the supplier's specifications (Boehringer Mannheim, Mannheim, Germany [18]). The hybridisation experiments on RAPD products blotted onto the appropriate membranes were performed as required for the use of DIG labelled probes (Boehringer Mannheim, Mannheim).

\subsection{Data analysis}

Photographs of the agarose gels in which the RAPD markers were resolved were scanned and analysed using the Fragment Analysis Program (Molecular DynamicsAmersham Life Science, Amersham, Buckinghamshire, UK). The different RAPD markers were identified according to the primer used and their size. The presence or absence of each marker was scored in each species to make comparisons between them. Nei's similarity index [28] was used to compare pairs of species:

$$
\mathrm{S}=2 \mathrm{~N}_{\mathrm{AB}} /\left(\mathrm{N}_{\mathrm{A}}+\mathrm{N}_{\mathrm{B}}\right)
$$

where $\mathrm{N}_{\mathrm{AB}}$ is the number of RAPD markers simultaneously present in the two species being compared, and $\mathrm{N}_{\mathrm{A}}$ and $\mathrm{N}_{\mathrm{B}}$ are the total number of RAPD markers present in the species $A$ and $B$, respectively. The similarity values among species were used to cluster species using the unweighted pair group method average (UPGMA) algorithm [38]. 


\section{RESULTS}

\subsection{RAPD markers}

In order to develop a system useful for the classification of seeds and plants belonging to the genus Prosopis, the polymorphism of randomly amplified DNA fragments (RAPD) present in 15 species belonging to this genus (table $I$ ) was analysed using random primer oligonucleotides (Operon Technologies Inc., Alameda, California, USA). A total of 1351 RAPD markers were identified in the analysed species (an average of 90 markers per species, table $I I$ ) which allowed a taxonomic study to be undertaken. Some specific amplified bands were particularly interesting because of their taxonomic potential and they were further analysed. When the oligonucleotide S20 (5'-TCTGGACGGA-3') was used as primer in PCR reactions for RAPD generation, among others, a molecular marker of approximately $0.380 \mathrm{kbp}\left(S 2 \mathrm{O}_{380}\right.$, figure 1a) was generated which was present in all the Prosopis species analysed. When the oligonucleotide S11 (5'-AGTCGGGTGG-3') was used as primer, the PCR reaction yielded, among others, a DNA fragment of $0.730 \mathrm{kbp}\left(S 11_{730}\right.$, figure $\left.1 \mathrm{~b}\right)$ which was present only in American species. Oligonucleotides S04 (5'-CACCCCCTTG-3') and S07 (5'- TCCGATGCTG-3') allowed the amplification of molecular markers which seemed to be species specific: the marker $S_{04}{ }_{983}$ was present in $P$. strombulifera, $P$. torquata and $P$. ferox (section Strombocarpa, figure $1 c$ ) whereas the markers $\mathrm{SO7}_{930}$ and $\mathrm{SO} 7_{1160}$ appeared in all species of section Algarobia except in $P$. kuntzei (figure $1 d$ ). The oligonucleotides S03 (5'-CAGAGGTCC-3') and L09 (5'-AGCAGGTGGA-3') yielded the most polymorphic RAPD profiles and allowed the differentiation of the all species (figure $1 e, f$ ) while primers L03 (5'-CCAGCAGCTT-3'), L08 (5'-AGCAGGTGGA-3'), L11 (5'-ACGATGAGCC-3'), S14 (5'-AAAGGGGTCC-3'), S16 (5'-AGGGGGTTCC-3') and S19 (5'GAGTCAGCAG-3') showed very little polymorphism among species (data not shown). It should be noted that all the oligonucleotides used as primers (except S20) produced profiles that differentiated $P$. cineraria, $P$. africana, $P$. argentina and $P$. kuntzei from the rest of Prosopis species.

Table II. Number of RAPD markers generated by each one of the oligonucleotide primers that revealed polymorphism among species.

\begin{tabular}{lccccccccccccccc}
\hline Primer & $\mathrm{C}$ & $\mathrm{A}$ & $\mathrm{S}$ & $\mathrm{T}$ & $\mathrm{Fe}$ & $\mathrm{Ar}$ & $\mathrm{K}$ & $\mathrm{H}$ & $\mathrm{Af}$ & $\mathrm{Ca}$ & $\mathrm{Ch}$ & $\mathrm{Fl}$ & $\mathrm{Al}$ & $\mathrm{P}$ & $\mathrm{N}$ \\
S03 & 7 & 8 & 10 & 10 & 10 & 7 & 9 & 6 & 7 & 7 & 7 & 8 & 8 & 8 & 9 \\
S04 & 7 & 4 & 11 & 7 & 7 & 9 & 8 & 6 & 7 & 5 & 7 & 10 & 9 & 5 & 7 \\
S07 & 5 & 8 & 4 & 2 & 4 & 1 & 3 & 2 & 2 & 2 & 2 & 3 & 2 & 2 & 3 \\
S11 & 7 & 5 & 6 & 5 & 5 & 9 & 4 & 3 & 3 & 4 & 5 & 5 & 5 & 4 & 5 \\
S14 & 8 & 6 & 10 & 8 & 8 & 5 & 10 & 8 & 8 & 8 & 10 & 7 & 7 & 7 & 6 \\
S16 & 10 & 12 & 8 & 9 & 8 & 6 & 10 & 8 & 6 & 7 & 7 & 5 & 9 & 6 & 6 \\
S19 & 9 & 8 & 10 & 11 & 12 & 7 & 7 & 9 & 8 & 7 & 10 & 9 & 8 & 13 & 12 \\
S20 & 5 & 6 & 4 & 6 & 8 & 11 & 3 & 8 & 2 & 2 & 5 & 3 & 5 & 3 & 2 \\
L03 & 6 & 7 & 3 & 7 & 6 & 8 & 5 & 6 & 10 & 8 & 10 & 11 & 8 & 10 & 9 \\
L08 & 11 & 10 & 6 & 6 & 8 & 8 & 7 & 6 & 13 & 8 & 8 & 10 & 6 & 9 & 10 \\
L09 & 10 & 6 & 8 & 3 & 8 & 9 & 12 & 13 & 9 & 10 & 10 & 11 & 9 & 5 & 7 \\
L11 & 14 & 12 & 14 & 9 & 7 & 12 & 10 & 11 & 12 & 11 & 13 & 14 & 16 & 15 & 15 \\
Total & 99 & 92 & 94 & 83 & 91 & 92 & 88 & 86 & 87 & 79 & 94 & 96 & 92 & 87 & 91 \\
\hline
\end{tabular}

Names codes: C, P. cineraria; A, P. africana; S, P. strombulifera; T, P. torquata; Fe, P. ferox; Ar, P. argentina; K, P. kuntzei; H, $P$. hassleri; Af, P. affinis; Ca, P. caldenia; Ch, P. chilensis; Fl, P. flexuosa; Al, P. alba; P, P. alba var. panta; N, $P$. nigra. 
A

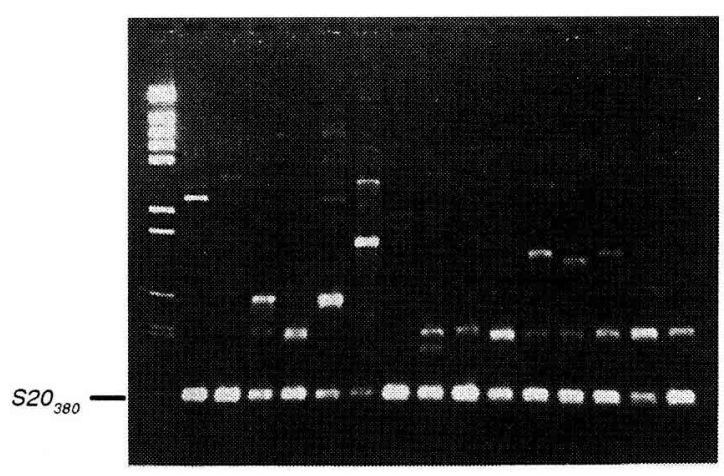

$M$ C A S T FeAr K H AfCaChFI Al P N

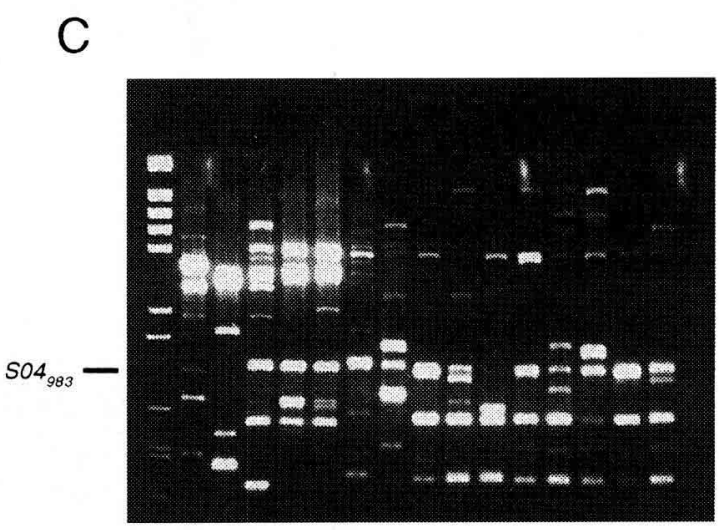

M C A $S$ T Fe Ar K h Af CaChFI Al P N

E

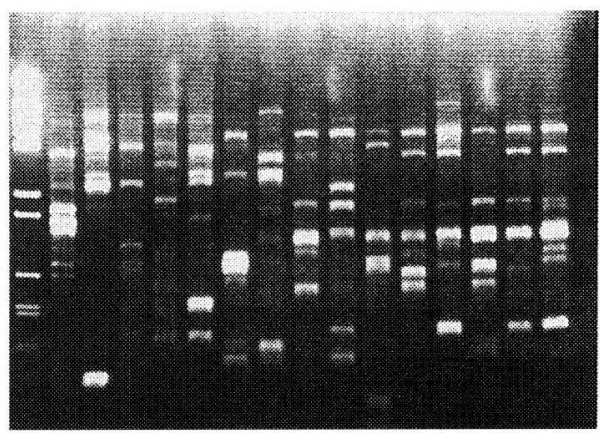

M C A $\mathbf{S} T$ Fe Ar K H Af CaChfi Al P $\mathbf{N}$
B

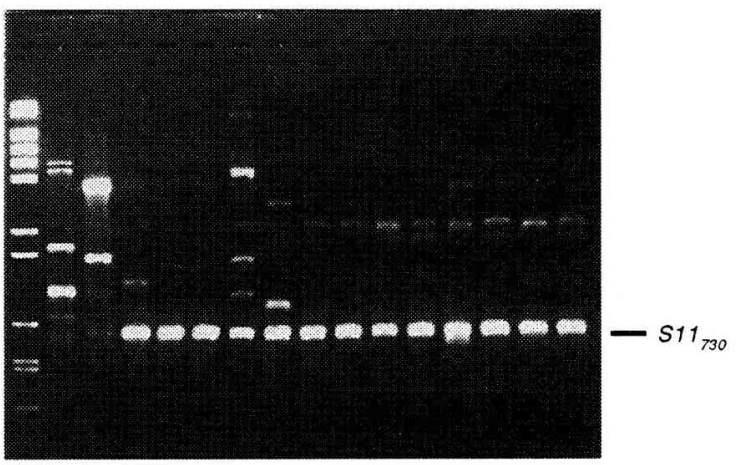

M C A $S$ T Fe Ar K H Af CaChFl Al P $N$

D

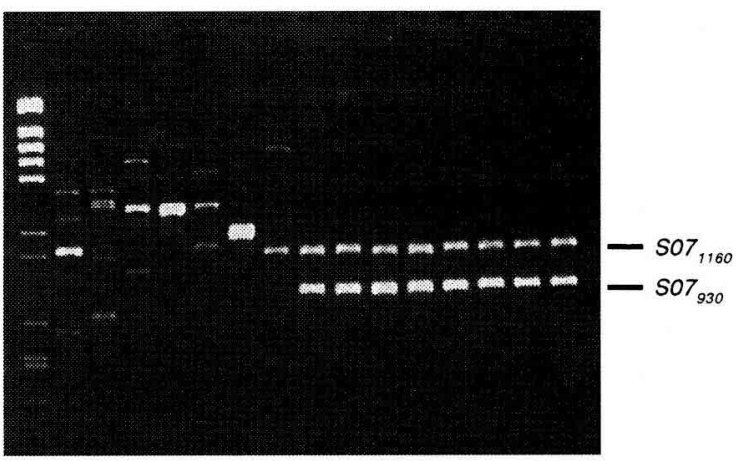

M C A S T FeAr K H Af CaChFl Al P $N$

F

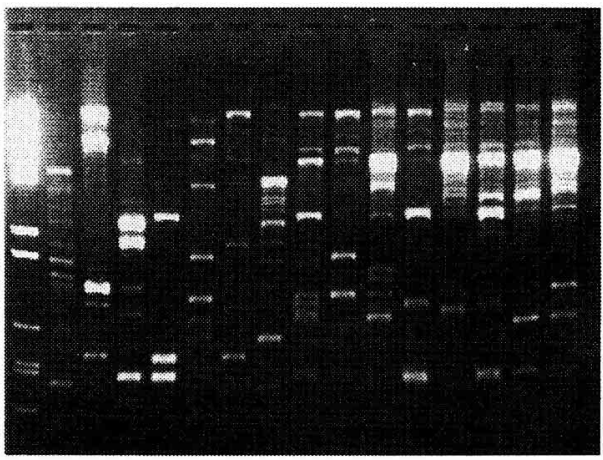

$M$ C A $S$ T FeAr K h Af CaCh FI Al P $N$

Figure 1. Examples of different RAPD molecular markers generated by using various primer oligonucleotides and the collection of Prosopis species studied in this paper. The primers used are: (A) S20, (B) S11, (C) S04, (D) S07, (E) S03 and (F) L09. The sequence of each primer is described in the text. Lane names: $\mathrm{M}$, molecular size marker; $\mathrm{C}, P$. cineraria; A, $P$. africana; $\mathrm{S}, P$. strombulifera; $\mathrm{T}$, P. torquata; Fe, P. ferox; Ar, P. argentina; K, P. kuntzei; H, P. hassleri; Af, P. affinis; $\mathrm{Ca}, P$. caldenia; Ch, $P$. chilensis; Fl, P. flexuosa; Al, P. alba; P, P. alba var. panta; N, P. nigra. 


\subsection{RAPD markers identity}

The identification of species on the basis of their RAPD profile relies on the assumption that bands of the same size appearing in different individuals correspond to identical sequences and not only to a circumstantial coincidence in size. In order to test this assumption two different kinds of experiments were performed: i) RAPD analysis of restriction digested DNA plant material; and ii) hybridisation experiments with cloned RAPD markers.

The molecular marker $S 07_{1160}$ appeared in all the species belonging to the section Algarobia (figure ld). In order to check if the RAPD bands corresponding in size to S07 1160 and present in these species were related not only in size but also in sequence, the restriction sites present in marker SO $7_{1160}$ were determined. For this purpose, the band corresponding to this marker was cloned in the pGEM-T vector yielding the plasmid pS07 1160 Only one isolation of this plasmid was studied further, and, hence, it represents the cloning of the amplification product of a single molecule of the pool of DNA and not a pool of DNA fragments. The restriction analysis of the cloned fragment revealed the presence of a site for the enzyme Pst I in the DNA sequence of the cloned S07 1160 marker. The presence of this Pst I site in every species of the Algarobia section was studied as follows: separate pools of genomic DNA corresponding to each one of the species belonging to the Algarobia section (with the exception of $P$. kuntzei in which the marker was absent, see below) were completely digested with PstI and used as template in separate PCR reactions designed to amplify the RAPD markers using the oligonucleotide S07 as primer for the reaction. Undigested DNA from each one of the different pools was used as control for the experiment. It could be seen that the molecular marker $S_{07}{ }_{1160}$ was absent in the PCR reactions performed using Pst I digested DNA as template, whereas it was present when the undigested material was used (figure 2a). These results indicated that a Pst I restriction site is present within the genomic sequence that gives rise to the marker $S 07_{1160}$ in every one of the analysed species. The failure in $S 07_{1160}$ amplifica-
A

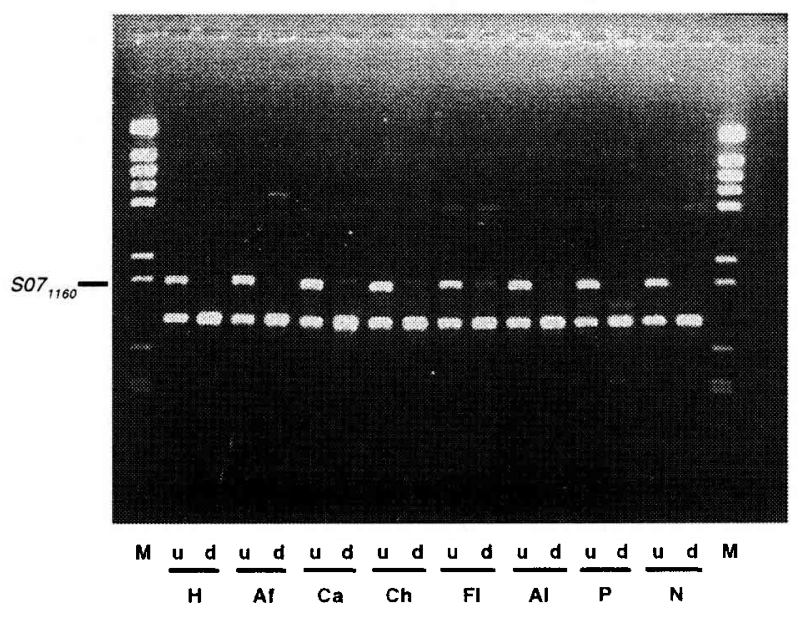

B

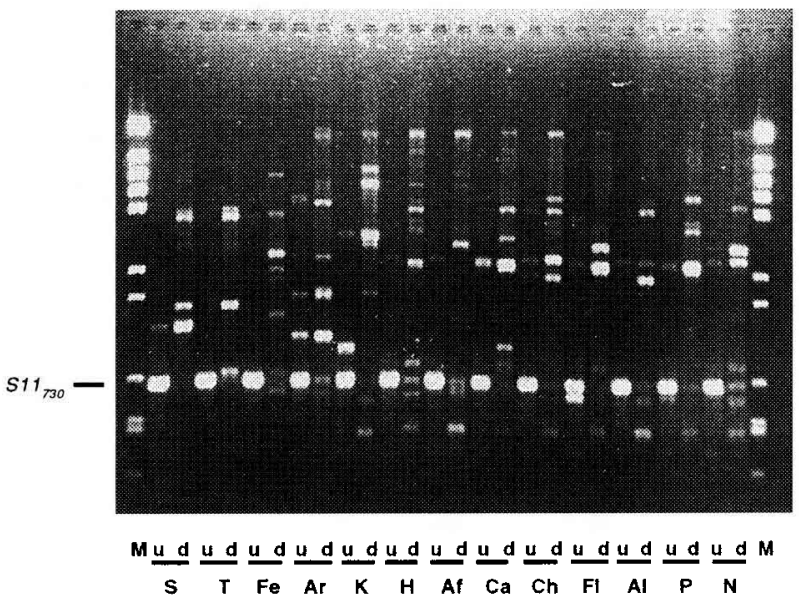

Figure 2. Effect of the digestion of the genomic DNA with PstI on the amplification of the molecular markers $S O 7_{1160}$ and $\mathrm{SI}_{730}$. (A) Genomic DNA from the Prosopis species belonging to the section Algarobia was used as template and the oligonucleotide $\mathrm{S} 07$ as primer. (B) Genomic DNA from American Prosopis was used as template and the oligonucleotide S11 as primer. The sequence of cach primer is described in the text. In both cases, (u) indicates undigested DNA used as template and (d) indicates digested DNA used as template. Lane names: M, molecular size marker; S, P. strombulifera; T, $P$. torquata; Fe, P. ferox; Ar, P. argentina; K, $P$. kuntzei; H, P. hassleri; Af, P. affinis; Ca, P. caldenia; Ch, P. chilensis; Fl, P. flexuosa; Al, P. alba; P, P. alba var. panta; N, P. nigra. 
tion when PstI digested DNA was used as template indicates that the restriction of the DNA at the PstI site set apart the annealing sites for the $\mathrm{S} 07$ oligonucleotide used as primer avoiding, in this way, the amplification of this molecular marker. A similar experiment was carried out to analyse the band corresponding to the marker $S 11_{730}$ (exclusive to the Prosopis American species, figure $1 b$ ). In this case, the cloned RAPD marker gave rise to plasmid

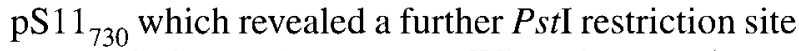
present in its DNA sequence. When the experiment described above for marker $S 07_{1160}$ was repeated for marker $S 11_{730}$, similar results were obtained (figure $2 b$ ) indicating that also in this case the similarity in size of the band appearing in different species reflected a similarity in sequence between all them.

The failure in the amplification of a given RAPD marker can be caused by minor differences at the annealing sites for the oligonucleotide used as primer or by major differences in the genomic region tagged by this particular marker. In order to test if the absence of a given species-specific molecular marker in a species is due to minor or major genetic differences, the RAPD marker can be used as probe in DNA hybridisation experiments to analyse its presence in the different species subjected to analysis. In this way, DNA fragments derived from $\mathrm{pSO}_{983}, \mathrm{pSO} 7_{930}, \mathrm{pS0} 7_{1160}, \mathrm{pS} 11_{730}$ and

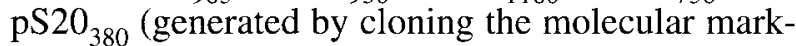
ers $S 04_{983}, S O 7_{930}, S O 7_{1160}, S 11_{730}$ and $S 2 O_{380}$ in pGEM-T, respectively; figure 1) were used as probes to reveal the presence of the molecular marker in PCR amplification reactions designed to produce the respective RAPD markers in the different Prosopis species being analysed. In this case, the PCR reactions were performed with only 20 amplification cycles to prevent the overamplification reaction that increases the concentration of unspecific amplification products [12]. The results obtained showed that the molecular marker $S 20_{380}$ appeared in all the species analysed in this study (figure 3a), the marker $S 11_{730}$ was specific for the Prosopis of American origin (at least the Prosopis species analysed in this paper) (figure $3 b$ ), and markers $\mathrm{SO}_{983}$ and $\mathrm{SO} 7_{1160}$ were section specific (figure $3 c, d$, respectively). It is important to point out that the RAPD band appearing in P. kuntzei which corresponds in size to marker $S 07_{1160}$ (figure Id) does not correspond to the same marker present in the other species of this section because it does not hybridise to the probe derived from the corresponding plasmids (figure $3 d$ ). Finally, the lack of hybridisation in these experiments reflects that $P$. kuntze $i$ has a low degree of relatedness to the rest of the Prosopis species analysed in this study.

\subsection{Analysis of similarity and clustering of Prosopis species}

The RAPD profiles of the different Prosopis species can be compared by numerical taxonomic techniques to evaluate the degree of relatedness between the different species. Twelve out of the 40 oligonucleotide primers used in this study yielded reproducible RAPD markers useful for taxonomic studies. Each primer amplified a variable number of DNA fragments ranging from only one fragment amplified by the oligonucleotide S07 in $P$. argenti$n a$ to 16 different loci amplified by oligonucleotide L11 in $P$. alba. The average number of RAPD markers per species used for the taxonomic study was of 90. The total number of DNA bands obtained in each one of species (table II) and the number of bands shared by each pair of species, allowed the construction of a similarity matrix (table III) using the Nei similarity index [28]. As it can be seen the lowest similarity value corresponded to the pair formed by $P$. africana and $P$. nigra, and the highest value was shown by the pair $P$. alba var. panta and P. nigra.

The different species were clustered according to the similarity between their RAPD profiles using the UPGMA (unweighted pair group method average) method [38] (figure 4). The cluster analysis revealed two major clusters: one formed by $P$. cineraria (section Adenopsis) and $P$. africana (section Anonychium), both species of the Old World, whereas the other group was complex and it contained two subgroups. The first subgroup was formed by three species: $P$. strombulifera and $P$. torquata (series Strombocarpae), and $P$. ferox (series Cavenicarpae). Both series belong to section 
A
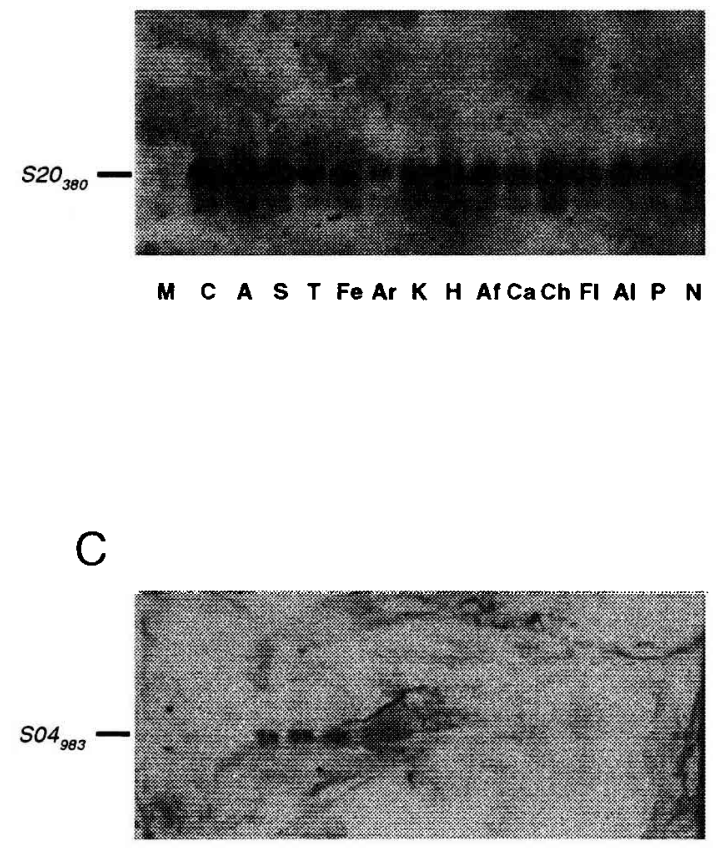

M C A $S$ T Fe Ar K H Af CaCh FI Al P $\mathbf{N}$
B

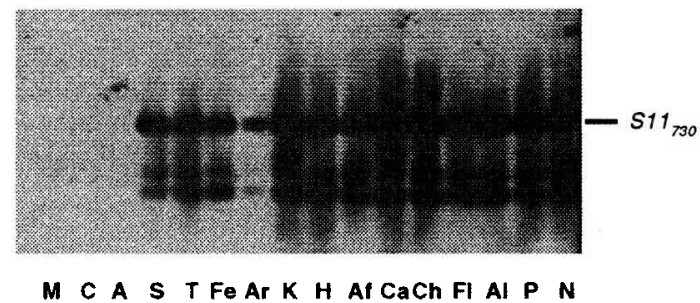

$\mathrm{D}$

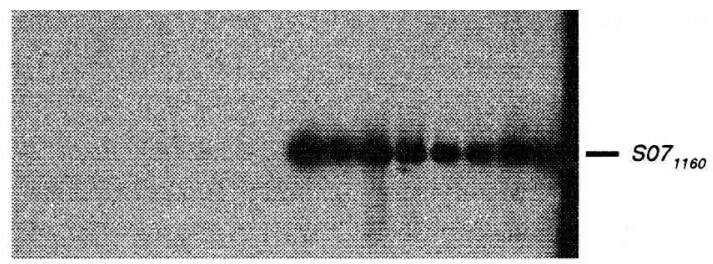

M C S A T Fe Ar K H Af CaCh FI Al P N

Figure 3. Detection of the presence of molecular markers by DNA hybridisation. (A) Hybrisation of $S 20_{380}$ on the PCR amplification products produced using $\mathrm{S} 20$ as oligonucleotide primer and the genomic DNA from each one of the 15 Prosopis species as template. (B) Hybridisation of $\mathrm{SII}_{730}$ on the PCR products generated by using SII as primer. (C) Hybridisation of $\mathrm{SO4}_{983}$ on the PCR products generated by using S04 as primer. (D) Hybridisation of $\mathrm{S}_{1160}$ on the PCR products generated by using S07 as primer. The sequence of each primer is described in the text. Lane names: $\mathrm{M}$, molecular size marker; C, P. cineraria; A, $P$. africana; $\mathrm{S}, P$. strombulifera; T, $P$. torquata; Fe, P. ferox; Ar, P. argentina; K, P. kuntzei; $\mathrm{H}, P$. hassleri; Af, $P$. affinis; $\mathrm{Ca}, P$. caldenia; Ch, $P$. chilensis; $\mathrm{Fl}, P$. flexuosa; Al, P. alba; P, P. alba var. panta; N, P. nigra.

Strombocarpa. The second subgroup was more complex and formed by the species of the section Algarobia and $P$. argentina (series Monilicarpa): $P$. nigra, $P$. alba var, panta, $P$. flexuosa, $P$. chilensis and $P$. alba (all of them belonging to the series Chilensis), clustered with $P$. hassleri (series Ruscifolia). P. caldenia (series Chilensis) clustered to $P$. affinis (series Pallidae). $P$. kuntzei (series Sericanthae) joined the cluster of the other species of the section Algarobia with the lowest similarity value.

\section{DISCUSSION}

In this paper, we report the use of RAPD markers to corroborate the taxonomy of 15 species belonging to the complex genus Prosopis. These species were analysed using standard protocols [22] to extract DNA from cotyledons modified to overcome difficulties caused by the high levels of carbohydrates and tannins in cotyledons. The modifications were related to the grinding of the plant material and the times and volumes of the reaction steps. Several phenol extractions and the treatment with RNAses appeared to be critical in obtaining DNA of high enough quality $\left(\mathrm{OD}_{260} / \mathrm{OD}_{280}\right.$ of 1.7-1.9) and yield (100 $\mu \mathrm{g} 100 \mathrm{mg}^{-1}$ of plant tissue) to allow several analyses of a given individual without compromising its survival.

The RAPD marker approach was chosen because previous authors including Saidman [32] and de la Vega [11] used isozyme markers and reported little 
Table III. Matrix of similarity among the Prosopis species studied in this paper.

\begin{tabular}{lcccccccccccccc}
\hline & $\mathrm{C}$ & $\mathrm{A}$ & $\mathrm{S}$ & $\mathrm{T}$ & $\mathrm{Fe}$ & $\mathrm{Ar}$ & $\mathrm{K}$ & $\mathrm{H}$ & $\mathrm{Af}$ & $\mathrm{Ca}$ & $\mathrm{Ch}$ & $\mathrm{Fl}$ & $\mathrm{Al}$ & $\mathrm{P}$ \\
\hline $\mathrm{A}$ & 0.126 & & & & & & & & & & & & & \\
$\mathrm{~S}$ & 0.093 & 0.107 & & & & & & & & & & & \\
$\mathrm{~T}$ & 0.066 & 0.103 & 0.621 & & & & & & & & & & \\
$\mathrm{Fe}$ & 0.095 & 0.131 & 0.432 & 0.563 & & & & & & & & & \\
$\mathrm{Ar}$ & 0.115 & 0.076 & 0.097 & 0.103 & 0.098 & & & & & & & & \\
$\mathrm{~K}$ & 0.096 & 0.078 & 0.132 & 0.105 & 0.145 & 0.144 & & & & & & & & \\
$\mathrm{H}$ & 0.086 & 0.090 & 0.167 & 0.142 & 0.147 & 0.146 & 0.276 & & & & & & & \\
$\mathrm{Af}$ & 0.054 & 0.101 & 0.110 & 0.106 & 0.146 & 0.112 & 0.183 & 0.474 & & & & & & \\
$\mathrm{Ca}$ & 0.079 & 0.094 & 0.116 & 0.099 & 0.106 & 0.140 & 0.216 & 0.485 & 0.494 & & & & & \\
$\mathrm{Ch}$ & 0.072 & 0.086 & 0.117 & 0.102 & 0.130 & 0.129 & 0.198 & 0.578 & 0.497 & 0.486 & & & \\
$\mathrm{Fl}$ & 0.061 & 0.074 & 0.137 & 0.123 & 0.160 & 0.106 & 0.239 & 0.450 & 0.459 & 0.469 & 0.516 & & & \\
$\mathrm{Al}$ & 0.073 & 0.065 & 0.108 & 0.103 & 0.131 & 0.109 & 0.233 & 0.506 & 0.402 & 0.491 & 0.667 & 0.543 & & \\
$\mathrm{P}$ & 0.094 & 0.065 & 0.129 & 0.126 & 0.142 & 0.130 & 0.221 & 0.494 & 0.413 & 0.468 & 0.538 & 0.564 & 0.598 & \\
$\mathrm{~N}$ & 0.092 & 0.053 & 0.105 & 0.112 & 0.139 & 0.106 & 0.217 & 0.450 & 0.372 & 0.446 & 0.474 & 0.573 & 0.564 & 0.766
\end{tabular}

Names codes: C, P. cineraria; A, P. africana; S, P. strombulifera; T, P. torquata; Fe, P. ferox; Ar, P. argentina; K, $P$. kuntzei; H, $P$. hassleri; Af, P. affinis; Ca, P. caldenia; Ch, P. chilensis; Fl, P. flexuosa; Al, P. alba; P, P. alba var. panta; N, P. nigra.

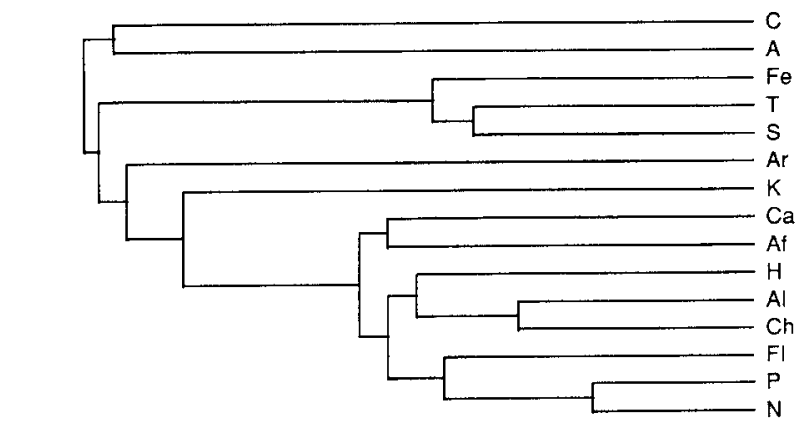

\begin{tabular}{cc|c|c|c|c|c|c|c|c|c|}
\hline & 1 & & $T$ & & $\mid$ & $\mid$ & $\mid$ & $\mid$ & $\mid$ \\
0.0 & 0.1 & 0.2 & 0.3 & 0.4 & 0.5 & 0.6 & 0.7 & 0.8 & 0.9 & 1.0 \\
Similarity index & &
\end{tabular}

Figure 4. Dendrogram showing the estimates of the percentage of similarity among the fifteen Prosopis species. The Nei similarity index [28] and the UPGMA clustering algorithm were used. Species names: C, $P$. cineraria; A, $P$. africana; Fe, $P$. ferox; T, $P$. torquata; S, $P$. strombulifera; Ar, P. argentina; $\mathrm{K}$, $P$. kuntzei; Ca, P. caldenia; Af, $P$. affinis; $\mathrm{H}, P$. hassleri; Al, $P$. alba; Ch, P. chilensis; Fl, P. flexuosa; P, P. alba var. panta; N, P. nigra.

genetic differentiation among Prosopis species. Burghardt and Palacios [6] showed that the electrophoretic analysis of seed proteins could distinguish between species in the five sections proposed by Burghardt $[7,8]$ but not between species within the section Algarobia. de la Vega [11] showed that the genetic distance, according to Nei's statistics [27], ranged from D: 0.065 (P. nigra-P. alba var. panta) to D: 0.249 (P. nigra-P. elata). Both authors proposed that the low values obtained could be due, among other factors, to intra and interloci hybrids in loci such as alcohol dehydrogenase (ADH) and aspartate aminotransfrase (AAT), or to a high number of common alleles among species. Molecular markers, on the other hand, have the advantage over biochemical markers of being independent of both biotic and abiotic environmental influences.

Because the seeds of some of the species examined were obtained from more than one provenance, DNA from ten randomly selected individuals (pooled DNA) was taken as representative of the species. This strategy, developed by Michelmore et al. [24] ensures that when amplification reactions take place, DNA sequences present in all or most individuals are revealed, while those appearing in only one individual are diluted. This prevents the erroneous inclusion of solitary or unique sequences as species-specific molecular markers. Twelve out of the 40 oligonucleotides used as primers gave suf- 
ficiently robust information to differentiate the Prosopis species providing clear cut and reproducible amplification profiles.

According to Burkart [7, 8], the genus Prosopis could have originated in tropical Africa at the end of the Mesozoic or beginning of the Tertiary era before westward and eastward migrations took place. $P$. africana, the least evolved species, persists in West Africa. The differences detected by molecular markers between $P$. cineraria and $P$. africana, both Old World species, and between these species and the New World species examined is possibly due to the strong speciation processes they have undergone, and confirms their position in different sections of the genus. The highly distinct profiles obtained for $P$. argentina may be due to its endemic characteristic. Burkart $[7,8]$ placed $P$. argentina in the monospecific section Monilicarpa on the basis of morphological characteristics but stated that the origin and affinities of this species were unclear. Our results obtained using molecular markers confirm the distinct character of $P$. argentina. Recent studies using electrophoresis of seed proteins [6] similarly confirmed the position of $P$. argentina in its own intermediate section.

When estimates of genetic relationships among individuals, strains, populations or species are obtained, it is assumed that co-migrating RAPD fragments present are homologous. Hybridisation and restriction digestion experiments as suggested by Williams et al. [43] and Rieseberg [31] demonstrated that homologous fragments usually contain similar sequences.

Prosopis, at 125 million years old, is one of the most primitive genera within the subfamily Mimosoidae of the family Leguminosae [7, 8]. Despite the time which has elapsed since the genus arose, hybridisation techniques have revealed a molecular marker $\left(\mathrm{S}_{2} \mathrm{O}_{383}\right.$ ) common to both Old and New World species. The finding of a RAPD marker $\left(S 11_{730}\right)$ hybridising only in American species raises questions about the origin of that marker around the beginning of the Tertiary era when separation of continents is presumed to have taken place. Section-specific molecular markers have also been found for the sections Algarobia $\left(\mathrm{SO}_{930}\right.$ and
SO7 1130 ) and Strombocarpa $\left(\mathrm{SO4}_{983}\right)$. These markers showed similar restriction digestion and hybridisation patterns in all species and sections, except in $P$. kuntze (section Algarobia), which appeared to be the only one distinct by these techniques because it lacks the Algarobia section-specific markers. This observation indicates the need for a more detailed analysis of $P$. kuntzei with additional primers or other kinds of molecular markers, and for a comparison of the amplification profiles of this species with those of $P$. sericantha, the only other species placed by Burkart $[7,8]$ in the series Sericanthae of the section Algarobia.

Electrophoretic studies by Burghardt [6] did not reveal any distinct differences in seed proteins among species in the section Algarobia although these authors analysed species from the series Ruscifoliae, Pallidae and Chilensis only and not from the series Sericanthae which contains $P$. kuntzei.

The use of RAPD markers to group species of Prosopis was clear enough to distinguish the five sections belonging to this genus. Similarities between sections are very low. This suggests that profound speciation has taken place between sections. However the results suggest that regrouping of species within the section Algarobia may be required. For example, molecular techniques reveal a cluster of $P$. chilensis and $P$. alba (series Chilensis) with $P$. hassleri (series Ruscifolia). These results fit with those of Palacios et al. (quoted by Burkart [8]) who reports a putative $P$. hassleri $\times P$. alba hybrid in Formosa (north of Argentina). Moreover, Burghardt [5], Palacios and Bravo [30], and Saidman [32, 33], studying seminal proteins, phenolic compounds and isozymes, found a very close similarity between $P$ alba and $P$. hassleri. Similarly, $P$. caldenia (series Chilensis) and $P$. affi$n$ is (series Pallidae) form a cluster although there is not a conclusive explanation for it. In spite of being $P$. affinis a species widely distributed (southern part of Bolivia, Paraguay, east of Argentina, south of Brazil and west of Uruguay) there are no data on possible hybrids between these species and some others belonging to series Chilensis except for an intermediate form $P$. pallidae (series Pallidae) $\times P$. 
juliflora (series Chilensis) described by Burkart [7, $8]$ in the topical rain forest of Ecuador.

The results of restriction digestions and hybridisation experiments in this study demonstrate that co-migrating bands have a high probability of being homologous. RAPD markers, combined with these other molecular techniques, represent valuable and powerful tools to identify homologous bands and hence to resolve the taxonomic relationships within the genus Prosopis. The robustness of the sectionspecific restriction digestions as well as hybridisation experiments will permit the rapid identification of new species and will help to solve the complex taxonomy of the genus and its hybrids.

Acknowledgements: This work was supported by a Research Project of the Programa de Cooperación Científica con Iberoamérica from the Ministerio de Educación y Ciencia (Spain), from the Royal Society Science Exchange Programme (U.K.) and by Funds of the Universidad Pública of Navarra (Spain).

\section{REFERENCES}

[1] Ahmad M., McNeil D.L., Fautrier A.G., Armstrong K.F., Patterson A.M., Genetic relationships in Lens species and parentage determination of their interspecific hybrids using RAPD markers, Theor. Appl. Genet. 92 (1996) 1091-1098.

[2] Baudracco-Arnas S., Pitrat M., A genetic map of melon (Cucumis melo L.) with RFLP, RAPD, isozymes, disease resistance and morphological markers, Theor. Appl. Genet. 93 (1996) 57-64.

[3] Bommineni V.R., Jauhar P.P., Peterson T.S., Chibbar R.N., Almouslem A.B., Analysis of hybribs of durum wheat with Thinopyrum junceiforme using RAPD markers, Theor. Appl. Genet. 95 (1997) 757-763.

[4] Bucci G., Vendramin G.G., Lelli L., Vicario F., Assessing the gentic divergence of Pinus leucodermis Ant. endargered populations: use of molecular markers for conservation purposes, Theor. Appl. Genet. 95 (1997) 1138-1146.

[5] Burghardt A.D., Palacios R.A., Caracterización electroforética de algunas especies de Prosopis (Leguminosae), XII Congreso Argentino de Genética (1981) 11.

[6] Burghardt A.D., Palacios R.A., Electrophoretic characterisation of American section of Prosopis L.
(Leguminosae: Mimosoideae), Bulletin of the International Group for the Study of Mimosoideae 20 (1997) 71-83.

[7] Burkart A., A monograph of the genus Prosopis (Leguminosae, subfam. Mimosoidae), J. Arnold Arboretum 57 (1976) 219-249.

[8] Burkart A., A monograph of the genus Prosopis (Leguminosae, subfam. Mimosoidae), J. Arnold Arboretum 57 (1976) 450-525.

[9] Chan K.F., Sun M., Genetic diversity and relationships detected by isozyme and RAPD analysis of crop and wild species of Amarathus, Theor. Appl. Genet. 95 (1997) 865-873.

[10] de Bustos A., Casanova C., Soler C. , Jouvé N., Rapid variation in wild populations of four species of the genus Hordeum (Poaceae), Theor. Appl. Genet. 96 (1998) 101-111.

[11] de la Vega A.S., Variabilidad genética y estructuración poblacional en especies del género Prosopis (Leguminosae) recurso biótico para reforestar zonas áridas, Ph.D. Thesis, Departamento de Producción Agraria, Universidad Pública de Navarra, Pamplona, Spain., 1996.

[12] Dieffenbach C.W., Dveksler G.S., PCR Primer. A laboratory manual, Cold Spring Harbor Laboratory Press, Cold Spring Harbor, USA, 1995.

[13] Felker P., Mesquite, an all purpose leguminose arid land tree, in: Ritchie G.A. (Ed.), New Agricultural Crops, Westview Press, Boulder, Colorado, USA, 1979, pp. 89-132.

[14] Felker P., Cannell G.H., Clark P.R., Variation in growth among 13 Prosopis (mesquite) species, Exp. Agr. 17 (1981) 209-218.

[15] Gresshoff P.M., Plant Genome Analysis, CRC Press, Boca Raton, Florida, USA, 1994.

[16] Harris P.J.C., Pasiecznik N.M., Bradbury M. , Ramírez L., Problems and potentials of Prosopis, in: Prendergast H.D.V., Etkin N.L., Harris D.R., Houghton P.J. (Eds.), Plants for Food and Medicine, Royal Botanical Gardens, Kew, UK, 1998, pp. 277-293.

[17] Hoey B.K., Crowe K.R., Jones W.M., Polans N.O., A phylogenetic analysis of Pisum based on morphological characters and allozyme and RAPD markers, Theor. Appl. Genet. 92 (1996) 92-100.

[18] Holtke H.J., Sagner G., Kessler C., Schmitz G., Sensitive chemiluminiscent detection of digoxigeninlabeled nucleic acids: a fast and simple protocol and its applications, BioTechniques 12 (1992) 104-113. 
[19] Iqbal M.J., Aziz N., Saeed N.A., Zafar I., Malik K.A., Genetic diversity evaluation of some elite cotton varieties by RAPD analysis, Theor. Appl. Genet. 94 (1997) 139-144.

[20] Khasa P.D., Dancik B.B., Rapid identification of wide-Engelmann spruce species by RAPD markers, Theor. Appl. Genet. 92 (1996) 46-52.

[21] Kojima T.J., Nagaoka T.P., Noda K., Ogihara Y., Genetic linkage map of ISSR and RAPD markers in Einlorn wheat in relation to that of RFLP markers, Theor. Appl. Genet. 96 (1998) 37-45.

[22] Lassner M.W., Peterson P., Yoder J.L., Simultaneous amplification of multiple DNA fragments by polymerase chain reaction in the analysis of transgenic plants and their progeny, Plant Mol. Biol. Reports 7 (1989) 116-128.

[23] Lennox E.S., Transduction of linked genetic characteres of the host by bacteriophage P1, Virology 1 (1955) 190-206.

[24] Michelmore R.W., Paran I., Kesseli R.V., Identification of markers linked to resistance genes by bulked segregant analysis: a rapid method to detect markers in specific genome regions by using segregating populations, Proc. Natl. Acad. Sci. USA 88 (1991) 9828-9832.

[25] Millán T., Osuna F., Cobos S., Torres A.M., Cubero J.I., Using RAPDSs to study phylogenetic relationships in Rosa, Theor. Appl. Genet. 92 (1996) 273-277.

[26] NAS, Firewood crops; shrubs and tree species for energy production, National Academic Press, Washington DC, USA, 1980.

[27] Nei M., Molecular Population, Genetics and Evolution, North-Holland Publishing Company, Amsterdam, Holland, 1975.

[28] Nei M., Li W.H., Mathematical model for studying genetic variation in terms of restriction endonucleases, Proc. Natl. Acad. Sci. USA 76 (1979) 5269-5273.

[29] Paillard M., Lashermes P., Pétiard V., Construction of a molecular linkage map in coffea, Theor. Appl. Genet. 93 (1996) 41-47.

[30] Palacios R.A., Bravo L.D., Hibridación natural en Prosopis (Leguminosae) en la región chaqueña argentina. Evidencias morfológicas y cromatográficas, Darwiniana 23 (1981) 3-35.

[31] Rieseberg L.H., Homolgy among RAPD fragments in interspecific comparisons, Mol. Ecol. 5 (1996) 99-106.
[32] Saidman B.O., Estudio de la variación alozímica en el género Prosopis, Ph.D. thesis, Fac. de Ciencias Exáctas, Físicas y Naturales, Universidad de Buenos Aires, Buenos Aires, Argentina, 1985.

[33] Saidman B.O., Isoenzymatic studies of alcoholdehydrogenase and glutamate-oxalacetate transaminase in four South-American species of Prosopis and their natural hybrids, Silvae Genet. 35 (1986) 3-10.

[34] Sambrook J., Fritsch E.F., Maniatis T., Molecular Cloning. A Laboratory Manual, Cold Spring Harbor Laboratory Press, Cold Spring Harbor, USA, 1989.

[35] Scovel G., Ben-Meir H., Ovadis M., Itzhaki H., Vainstin A., RAPD and RFLP markers tightly linked to the locus controlling carnation (Dianthus caryophyllus) flower type, Theor. Appl. Genet. 96 (1998) 117-122.

[36] Simpson B.B., Breeding systems of dominant perennial plants of two disjunct warn desert ecosystems, Oecologia 27 (1977) $203-226$.

[37] Simpson B.B., Solbrig O.T., Mezquite. Its Biology in Two Desert Ecosystems, Dowden, Hutchinson and Ross Inc., Pennsylvania, USA, 1977.

[38] Sneath P.H.A., Sokal R.R., Numerical Taxonomy. The Principles and Practice of Numerical Classification, W.H. Freeman and Company, San Francisco, USA, 1973.

[39] Solbrig O.T., Cantino P.D., Reproductive adaptations in Prosopis (Leguminosae, Mimosoideae), J. Arnold Arboretum 56 (1975) 185-210.

[40] Tautz D., Renz M., An optimized freezesqueezed method for the recovery of DNA from agarose gels, Anal. Biochem. 132 (1983) 14-19.

[41] Wang I.-H., Thomas C.E., Dean R.A., A genetic map of melon (Cucumis melo L.) based on amplified fragment length polymorphism (AFLP) markers, Theor. Appl. Genet. 95 (1997) 791-798.

[42] Weising K., Nybom H., Wolff K., Meyer W., DNA Fingerprinting in Plants and Fungi, CRC Press, Boca Raton, Florida, USA, 1995.

[43] Williams J.G.K., Kubelik A.R., Livak K.J., Rafalski J.A., Tingey S.V., DNA polymorphisms amplified by arbitrary primers are useful as genetic markers, Nucleic Acid Res. 18 (1990) 6531-6535.

[44] Xiao J., Li J., Yuan L., McCouch S.R., Tanksley S.D., Genetic diversity and its relationship to hybrid performance and heterosis in rice as revealed by PCR-based markers, Theor. Appl. Genet. 92 (1996) 637-643. 